\title{
Phenomenon of Paternal Involvement in the Discourse of the Educational Potential of Fatherhood
}

\author{
Alexander Chekhonin candidate of pedagogical sciences \\ Tyumen State University, Russian Federation \\ nobunaga@yandex.ru
}

\begin{abstract}
This article provides an analysis of the relevant data on the research of the phenomenon of paternal involvement. For consideration by the international scientific community, the author proposes the classification of modern studies of the phenomenon of involvement in the world humanitarian discourse. Also, the article describes the significant correlations of paternal involvement with other structural components of the construct of the educational potential of fatherhood, identified in the original author's research aimed at creating tools for assessing the educational potential of fatherhood and practical probation and verifying the validity of this technique. Having determined the direct significant correlations between the competence of fathers and the frequency and frequency of their educational and educational actions, the author conclude that the need to enhance the participation of fathers by creating the community of fathers, which will maintain the current and necessary level of motivation to participate in the system of father-child interaction.
\end{abstract}

Keywords: parenting, involvement, paternal involvement, the educational potential of fatherhood, father-child interaction, adult education.

\section{Introduction}

Today, fatherhood is explored in the focuses of various sciences. In modern studies of the named phenomenology, the general characteristic of fatherhood is the concept of involvement and there are dozens of publications of other researchers that reflect the concept of paternal involvement in various qualitative aspects. H. Norman (2015), continuing the M.E. Lamb concept (Lamb, 2008), according to which paternal involvement consists of joint sessions with the child, the actual availability of the father, i.e. his real presence. Also, according to Lamb, involvement implies responsibility, understood as the need to participate in the child's life. However, in real practice, the father's motivation may be limited by various individual (internal) and external factors (his family situation, his relationship with his wife, his work schedule, the level of earnings, etc.), which indicates the multifactorial involvement and expands the classical conceptualization of involvement.

According to K. Mclaughlin, O. Muldoon (2016), one of the significant factors is the employment of the father and the modern social patterns. The researchers note that today fathers should play the role of a "new father", that is typical for the current social discourse and means active care of the children. At the same time, the society expects fathers to remain committed to their professional roles as earners and workers. The result is that modern fathers are subjected to similar pressures as women when they first appeared in the workplaces. The author notes the significant tension between the new ideals of fatherhood and its real practice, generated by expectations and the actual social situation. It is important to note that this observation is absolutely true for different contemporary cultures and societies. According to A.J. Marchin (Marchin, 2015), today, the society needs a transformation of social relations, which will lead to the removal of the contradictions between the desire of modern fathers to be engaged in the education of their children and their employment in the workplace.

The study of the gender attitudes of fathers and their correlation with the degree of involvement in the upbringing of the child, published by J.K. Karre (2016), showed that the traditional model of the father, "disappearing" at work is not effective. J.K. Karre points out the paradoxical feature of the traditional egalitarian model and gender (primarily patriarchal) norms: the more men demonstrate commitment to the traditional image of the family, in fact, the less they are involved in the real upbringing of children.

Many publications are devoted to the problem of combining the father's upbringing and his work schedule in various aspects, including those considering not only the situation of exceptional workload, but also the paternity leave, which becomes popular in some western societies. In different aspects the correlation between the degree of father's involvement and his professional workload are investigated 
by S. Tanaka, J. Waldfogel (2007), J. Castillo, G. Welch, C. Sarver (2011), E. Lind, L. Parlin (2017), B.S. McGill (2014), J.B. Stykes (2015), G. Russell, C. Hwang (2004).

It is extremely difficult to draw up a holistic matrix of even the main research focuses in the question of clarification, definition, establishment and strong determination of the inner essence of paternal involvement. At the same time, the actual thematic topology of studies of the nature and specificity of paternal involvement, analysed by the author (as a result of the study of more than 300 modern scientific studies around the world, since 2000) are:

- analysis of paternal involvement in the situation of divorce or non-marital parenthood (Troilo, Coleman, 2013), as well as the situation of an "absent father";

- studies of the specifics of paternal involvement in whole (non-fragile) families (HohmannMarriott, 2011);

- studies of the educational involvement of single fathers or fathers in difficult life situations (Bronte-Tinkew, Scott, Lilja, 2010; Devault, Forget, Dubeau, 2015);

- research on the involvement of fathers in correlation with the aspect of family traditions in different national cultures (Ho et al., 2010; Nakazawa, Shwalb, 2013; Hofferth et al., 2013);

- analysis of the relationship between the quality of paternal involvement with the level of his income and professional employment (Cowan et al., 2009);

- scientific publications on the involvement of the father in his correlation with gender and sibling, age status of children (Paulson, Dauber, Leiferman, 2006);

- Comparative work on the comparison of the essence of paternal and maternal involvement and marital interaction in the aspect of child-rearing (McBride, Schoppe, Rane, 2002);

- studies of the influence of paternal involvement on the development of the child's personality in cognitive, affective, social and other aspects (Sarkadi et al., 2007);

- scientific analysis of father's involvement in the situation of the first experience of parenthood, and analysis paternal attitudes in the prenatal and postnatal period (Doherty, Erickson, LaRossa, 2006; Bich, Hoa, Malqvist, 2014);

- works devoted to the attempt of general theoretical conceptualization of the concept of paternal involvement in the mainstream of psychological and sociological sciences (Day, Lamb, 2004; Bulanda, 2004; Milkie, Denny, 2014).

The aim of the study is to identify significant correlations of paternal involvement with other structural components of the construct of the educational potential of fatherhood and to determine the direct significant correlations between the competence of fathers and the frequency and frequency of their educational and educational actions.

\section{Methodology}

In addition to the analysis of modern scientific literature and the construction of an actual classification of studies devoted to the phenomenon of involvement, the author conducted their own research aimed at creating tools for assessing the educational potential of fatherhood and practical probation and verifying the validity of this technique. The structural representation of the concept of educational potential of fatherhood is described in the article " Educational potential of fatherhood: conceptual foundations of research and support» of V.I. Zagvyazinsky, A.D. Chekhonin (2017).

By implementing a public survey in which fathers take part, the author builds the universal model of fatherhood, in which involvement is manifested as its structural part. Today, more than 700 people from different cities of Russia and abroad have been interviewed in personal conversations with respondents in writing, through social networks and the Internet. Answering the question "what does it mean to be a father?", men were defined in opinions on three positions - activity (concrete forms of involvement and interaction), meanings and ideals of fatherhood.

The author received a lot of answers (more than 2000 variants), the semantic classification of which allowed to identify three main markers of fatherhood: educational actions (what actions involves paternity), ideal ideas about child upbringing and education (how paternal involvement should be updated), and the motives and meanings of fatherhood (why and what for the father should be involved in the upbringing of the child). 
In turn, paternal involvement, as a component of the actualized educational potential of fatherhood, according to the respondents ' answers is structured on the following points:

- direct interaction between the father and the child (physical contact in joint work, games, sports, etc.)

- communication with the child and mentoring (story, dialogues with the child, active listening, etc.)

- initiative and interest (organization by the father of events in the life of a child with educational and entertainment vector - children's parties, concerts, etc.)

- active care of the child (assistance of the father, participation in the treatment of the child, financial support, etc.)

The author presented a methodology for assessing the educational potential of fatherhood, a questionnaire consisting of 213 questions. The practical approbation of the method in Russia allowed to determine several interesting aspects of the reflection of father's involvement, confirmed by the methods of mathematical statistics. The survey was conducted with participation of 200 men-fathers of different age, social and marital status. For statistical data analysis and presentation of research results, the author used the software package SPSS ("Statistical Package for the Social Sciences"), version 23 for Windows.

\section{Results and Discussion}

Through the processing of the survey results, indicators of descriptive statistics of such factors of educational actions as interaction, communication and mentoring, initiative and interest, support and care were obtained. Each of the factors was assessed in terms of competence and periodicity.

The biggest level of competence of fathers is observed in their support and care of the child. This figure ranges from 1.14 to 5 points relative to the average of 3.32. At the same time, half of the respondents have no less than 3.43 points. However, the variation of this feature is also the largest, the average values deviate from the average by 0.71 points. As the most undeveloped factor, fathers evaluate their competence in the aspects of initiative and interest. The value of this factor in half of the respondents does not exceed 2.71 points (Table 1 ).

Table 1

Descriptive statistics of competence of educational and upbringing actions of father

\begin{tabular}{|c|c|c|c|c|c|}
\hline & & Interaction & $\begin{array}{l}\text { Communication } \\
\text { and mentoring }\end{array}$ & $\begin{array}{c}\text { Initiative and } \\
\text { interest }\end{array}$ & Support and care \\
\hline \multicolumn{2}{|c|}{ Mean } & 3,02 & 2,95 & 2,66 & 3,32 \\
\hline \multicolumn{2}{|c|}{ Median } & 3,09 & 2,95 & 2,71 & 3,43 \\
\hline \multicolumn{2}{|c|}{ Std. Deviation } & 0,67 & 0,64 & 0,66 & 0,71 \\
\hline \multicolumn{2}{|c|}{ Range } & 3,55 & 3,45 & 3,43 & 3,86 \\
\hline \multicolumn{2}{|c|}{ Minimum } & 1,27 & 1,18 & 1,14 & 1,14 \\
\hline \multicolumn{2}{|c|}{ Maximum } & 4,82 & 4,64 & 4,57 & 5,00 \\
\hline \multirow[t]{3}{*}{ Percentiles } & 25 & 2,56 & 2,55 & 2,20 & 2,86 \\
\hline & 50 & 3,09 & 2,95 & 2,71 & 3,43 \\
\hline & 75 & 3,53 & 3,37 & 3,14 & 3,86 \\
\hline
\end{tabular}

The respondents rate the frequency of their support and care for children most highly. The lowest initiative and interest (Table 2).

Table 2

\section{Descriptive statistics of the periodicity of educational and upbringing actions of father}

\begin{tabular}{|c|c|c|c|c|c|}
\hline & & Interaction & $\begin{array}{c}\text { Communication } \\
\text { and mentoring }\end{array}$ & $\begin{array}{c}\text { Initiative and } \\
\text { interest }\end{array}$ & Support and care \\
\hline \multicolumn{2}{|l|}{ Mean } & 2,96 & 2,92 & 2,62 & 3,22 \\
\hline \multicolumn{2}{|l|}{ Median } & 2,91 & 2,91 & 2,57 & 3,29 \\
\hline \multicolumn{2}{|c|}{ Std. Deviation } & 0,75 & 0,71 & 0,71 & 0,81 \\
\hline \multicolumn{2}{|c|}{ Range } & 6,45 & 3,55 & 3,43 & 3,86 \\
\hline \multicolumn{2}{|l|}{ Minimum } & 1,27 & 1,18 & 1,14 & 1,14 \\
\hline \multicolumn{2}{|l|}{ Maximum } & 7,73 & 4,73 & 4,57 & 5,00 \\
\hline \multirow{3}{*}{ Percentiles } & 25 & 2,55 & 2,36 & 2,14 & 2,57 \\
\hline & 50 & 2,91 & 2,91 & 2,57 & 3,29 \\
\hline & 75 & 3,36 & 3,36 & 3,00 & 3,86 \\
\hline
\end{tabular}


There are significant differences between the assessment of competence and the periodicity of this factor. The level of competence of the respondents is significantly higher than the frequency of these educational activities. At the same time, there are no significant differences in the assessment of periodicity and competence in the assessment of other factors (Table 3).

Table 3

Results of application of the Student's criterion for dependent samples (the levels of competence of fathers and the periodicity of educational and upbringing actions of father)

\begin{tabular}{|l|l|c|}
\hline \multicolumn{2}{|l|}{} & Sig. (2-tailed) \\
\hline Pair 1 & Father-child interaction (competence) - Father-child interaction (periodicity) & 0,068 \\
\hline Pair 2 & $\begin{array}{l}\text { Communication and mentoring (competence) - Communication and } \\
\text { mentoring (periodicity) }\end{array}$ & 0,191 \\
\hline Pair 3 & Initiative and interest (competence) - Initiative and interest (periodicity) & 0,151 \\
\hline Pair 4 & Support and care (competence) - Support and care (periodicity) & 0,004 \\
\hline
\end{tabular}

Between the competence of fathers and the periodicity of educational and upbringing actions there are direct significant strong correlations. The higher the level of fathers` competence the higher periodicity of appropriate educational and upbringing actions is shown (Table 4 , where ** means significant correlation).

Table 4

\section{Coefficients of the correlation between the competence of fathers and the periodicity of educational and upbringing actions of father}

\begin{tabular}{|l|l|c|}
\hline \multicolumn{2}{|l|}{} & Correlation \\
\hline Pair 1 & Father-child interaction (competence) \& Father-child interaction (periodicity) & $0,762^{* *}$ \\
\hline Pair 2 & $\begin{array}{l}\text { Communication and mentoring (competence) \& Communication and mentoring } \\
\text { (periodicity) }\end{array}$ & $0,836^{* *}$ \\
\hline Pair 3 & Initiative and interest (competence) \& Initiative and interest (periodicity) & $0,814^{* *}$ \\
\hline Pair 4 & Support and care (competence) \& Support and care (periodicity) & $0,800^{* *}$ \\
\hline
\end{tabular}

The results allow to draw the following interpretations:

- There are direct significant correlations between the competence of fathers and the frequency and periodicity of their educational and upbringing actions. Therefore, in order to increase the involvement of fathers, it is necessary to improve their competence in the issues of children's upbringing. In this sense, the most productive approach, according to the author, is to create a reference community of fathers, which will maintain the current and necessary level of motivation for involvement as an approved system of action. Also, this community will create a system of regular activities aimed at universal education of the father's audience, according to its own requests.

- The results of the study show that the factor of interaction between fathers and children in the aspect of initiative and interest is reflexively assessed by fathers as the lowest. In this regard, the thesis proposed above, becomes even more relevant. Interest in the upbringing of the child, being uncharacteristic for many men, should be "fixed" by encouragement through its recognition in the reference community as dignity-base.

- The level of competence on all factors is estimated by fathers higher, than the level of frequency of educational actions. In further studies, it is necessary to analyse what factors do not allow fathers to fully realize their competence, as well as what factors actualize it.

\section{Conclusions}

The creation of conditions for qualitative improvement of the father's engagement is the actual goal. It can be achieved in the systemic interaction of a wide range of social institutions. Its essence is to ensure the creation of reference dialogue communities of fathers, support educational and training work, providing platforms for father-child and family interaction of long-term functioning. These social institutions should be the family, the education system, social support institutions, etc. At the same time, the social work should be based on the integration of the results of various studies of paternity, which 
will build it on the basis of actual arguments, logic and understanding of the necessary practical efforts. Paternal involvement is a necessary subject of modern research of the family Institute. Today it is becoming obvious that its absence leads to serious difficulties in the development of the child. The proposed research data of the author are taken into account in their current project "Father's meet-up" and are resonant in the real social practice of the Federal Council of fathers of Russia.

\section{Bibliography}

1. Bich T.H., Hoa D.T., Malqvist M. (2014). Fathers as Supporters for Improved Exclusive Breastfeeding in Viet Nam. Maternal and Child Health Journal, 18(6), 1444-1453.

2. Bronte-Tinkew J., Scott M.E., Lilja E. (2010). Single Custodial Fathers' Involvement and Parenting: Implications for Outcomes in Emerging Adulthood. Journal of Marriage and Family 72(5), $1107-1127$.

3. Bulanda R.E. (2004). Paternal Involvement with Children: The Influence of Gender Ideologies. Journal of Marriage and Family, 66(1), 40-45.

4. Castillo J., Welch G., Sarver C. (2011). Fathering: The relationship between fathers' residence, fathers' sociodemographic characteristics, and father involvement. Maternal and Child Health Journal, 15 (8), 1342-1349.

5. Cowan P.A., Cowan C.P., Pruett M.K., Pruett K., Wong J.J. (2009). Promoting fathers' engagement with children: preventive interventions for low-income families. Journal of Marriage and Family, 71 (3), 663-677.

6. Day R.D., Lamb M.E. (2004). Conceptualizing and measuring father involvement: pathways, problems, and progressIn R.D. Day, M.E. Lamb (Eds.), Conceptualizing and measuring father involvement. Mahwah, NJ, US: Lawrence Erlbaum Associates Publishers, 1-15.

7. Devault A., Forget G., Dubeau D. (Eds.). (2015). Fathering: Promoting Positive Father Involvement. USA: University of Toronto Press.

8. Doherty W.J., Erickson M.F., LaRossa R. (2006). An intervention to increase father involvement and skills with infants during the transition to parenthood. Journal of Family Psychology, 20(3), 438-447.

9. Ho H-Z., Chen W-W., Tran C.N., Ko C.T. (2010). Parental involvement in Taiwanese families: Father-mother differences. Childhood Education, 86(6), 376-381.

10. Hofferth S.L., Pleck J.H., Goldscheider F., Curtin S., Hrapczynski K. (2013). Family structure and men's motivation for parenthood in the United States. In N.J. Cabrera \& C.S. Tamis-LeMonda (Eds.), Handbook of father involvement: Multidisciplinary perspective. New York, NY, US: Routledge/Taylor \& Francis Group, 57-80.

11. Hohmann-Marriott B. (2011). Coparenting and Father Involvement in Married and Unmarried Coresident Couples. Journal of Marriage and Family, 73, 296 - 309

12. Karre J.K. (2016). Gender-Based Attitudes and Father Involvement: Amount, Assessment, and Desires for More. Fathering: a journal of theory and research about men as parents, 13(3), 231-244.

13. Lamb M. E. (2008). The history of research on father involvement, Marriage and Family Review, 29, 23-42.

14. Lind E., Parlin L. (2017). Work Education in the Family: Similarities and Differences between the City and Rural Areas. In V. Dislere (Ed.), The Proceedings of the International Scientific Conference Rural Environment. Education. Personality (REEP), 10. Jelgava: LLU TF, 352 - 359. Retrieved from: http://llufb.llu.lv/conference/REEP/2017/Latvia-Univ-Agricult-REEP-2017_proceedings.pdf

15. Marchin A.J. (2015). Mind the Gap: The Expectation and Reality of Involved Fatherhood. Fathering: a journal of theory and research about men as parents, 13(1), 36-59.

16. McBride B.A., Schoppe S.J., Rane T.R. (2002). Child characteristics, parenting stress, and parental involvement: Father versus mothers. Journal of Marriage and Family, 64(4), 998-1011.

17. McGill B.S. (2014). Navigating new norms of involved fatherhood: Employment, fathering attitudes, and father involvement. Journal of Family Issues, 1(18), 1089-1106. Retrieved from http://citeseerx.ist.psu.edu/viewdoc/download?doi=10.1.1.864.6402\&rep=rep1\&type $=\mathrm{pdf}$

18. Mclaughlin K., Muldoon O. (2016). Father Identity Involvement and Work-Family Balance: An Indepth Interview Study. Journal of Community and Applied Social Psychology, 24 (5), 439-452.

19. Milkie M.A., Denny K.E. (2014). Changes in the Cultural Model of Father Involvement: Descriptions of Benefits to Fathers, Children, and Mothers in Parents' Magazine, 1926-2006. 
Journal of Family Issues, 35(2), 223-253. Retrieved from

http://citeseerx.ist.psu.edu/viewdoc/download?doi=10.1.1.878.1353\&rep=rep1\&type=pdf

20. Nakazawa J., Shwalb D.W. (2013). Fathering in Japan: Entering an era of involvement with children. In D.W. Shwalb, B.J. Shwalb, M.E. Lamb (Eds.), Fathers in cultural context. New York: Routledge Academic, 42-67.

21. Norman H. (2015). Paternal involvement in childcare: How can it be classified and what are the key influences? Families, Relationships and Societies, 4(3), 89-105.

22. Paulson J.F., Dauber S.E., Leiferman J.A. (2006). Parental Depression, Relationship Quality, and Nonresident Father Involvement With Their Infants. Journal of Family Issues, 32(4), 528-549. Retrieved from

$\mathrm{http}: / /$ citeseerx.ist.psu.edu/viewdoc/download?doi=10.1.1.828.8551\&rep=rep1\&type=pdf

23. Russell G., Hwang C. (2004). The impact of workplace practices on father involvement. In M.E. Lamb (Ed.), The role of the father in child development. Hoboken, NJ, US: John Wiley and Sons Inc., 476-503.

24. Sarkadi A., Kristiansson R., Oberkaid F., Bremberg S. (2008). Fathers' involvement and children's development outcomes: A systematic review of longitudinal studies. Acta Paediatrica, 97(2), 153-158

25. Stykes J.B. (2015). What matters most? Money, relationships, and visions of masculinity as key correlates of father involvement. Fathering: a journal of theory and research about men as parents, 13 (1), 60-79.

26. Tanaka S., Waldfogel J. (2007). Effects of parental leave and work hours on fathers' involvement with their babies. Community, Work \& Family, 10(4), 409-426.

27. Troilo J., Coleman M. (2013). "I don't know how much more I can take". How divorced nonresidential fathers manage barriers to involvement? Fathering: a journal of theory and research about men as parents, 11(2), 159-178.

28. Zagvyazinsky V.I., Chekhonin A.D. (2017). The Educational potential of fatherhood: conceptual basis of research and support. The Education and science, 19(10), 106-127. 